\title{
PENGARUH TEKNOLOGI AKUAPONIK DENGAN MEDIA TANAM SELADA (Lactuca sativa) YANG BERBEDA TERHADAP PERTUMBUHAN BELUT (Monopterus albus)
}

\section{Aquaponics Technology Effect Planting Different Media of Lettuce (Lactuca sativa) in Growth Eels (Monopterus albus)}

\author{
Pipin Tri Anjani ${ }^{1 *}$, Rahayu Kusdarwati ${ }^{2}$ dan Sudarno ${ }^{2}$ \\ ${ }^{1}$ Program Studi Budidaya Perairan, Fakultas Perikanan dan Kelautan, Universitas Airlangga, Surabaya \\ ${ }^{2}$ Departemen Manajemen Kesehatan Ikan dan Budidaya Perairan, Fakultas Perikanan dan Kelautan, Universitas \\ Airlangga, Surabaya \\ *anjanipipin@gmail.com
}

\begin{abstract}
Abstrak
Teknologi akuaponik merupakan teknologi kombinasi akuakultur dan hidroponik yang bertujuan untuk memelihara ikan dan tanaman dalam satu sistem yang saling terhubung (Sibarani, 2013). Limbah yang dihasilkan oleh ikan seperti feses dan pakan, digunakan sebagai pupuk untuk tanaman. Kemudian air yang dialirkan dari media pemeliharaan dibersihkan olah tanaman sehingga dapat digunakan kembali oleh ikan (Wahap,2010). Menurut Rokocy (2010) interaksi antara ikan dan tanaman menghasilkan lingkungan yang ideal untuk tumbuh sehingga lebih produktif dari metode tradisional.Tujuan penelitian ini adalah untuk mengetahui pengaruh media tanam terhadap pertumbuhan belut (Monopterus albus) dalam sistem akuaponik. Penelitian ini dilakukan pada bulan Agustus sampai September 2016 di Fakultas Perikanan dan Kelautan Universitas Airlangga. Percobaan terdiri dari empat perlakuan dan lima ulangan, tanpa media tanam sebagai kontrol ( P0), media tanam zeolit (P1), media tanam batu apung (P2) dan media tanam pecahan batu bata (P3). Hasil pengamatan yang didapatkan dari penggunaan teknologi akuaponik dengan media tanam selada terbaik yang dapat mempengaruhi pertumbuhan belut yaitu media tanam zeolit. Pada pengamatan menunjukkan laju pertumbuhan spesifik dengan media tanam zeolit (1,19\%/hari), kelulushidupan belut dengan media tanam zeolit (70\%), Penambahan tinggi selada pada media tanam zeolit $(11,39 \mathrm{~cm})$, dan kandungan amonia terendah pada media tanam zeolit pada hari ke-28 $(0,03 \mathrm{mg} / \mathrm{L})$.
\end{abstract}

Kata Kunci: Akuaponik, Laju Pertumbuhan, Lactuca sativa, Monopterus albus, Media Tanam

\begin{abstract}
Aquaponics is the combination of aquaculture and hydroponic technology which aim to raise fish as well as grow the plants in an interconnected system (Sibarani, 2014). The wastes that are produced by fish such as feces and feed are used as plants fertilization. The water that is flowed from media culture will be filtered by the plants so that could be reused by fish (Wahap, 2010). According to Rokocy (2010) the interaction between fish and plants will creates an ideal environment for them to growing compared to the traditional method. The objective of this research is to find out the effect of cultivation media on the eel (Monopterus albus) growth in the aquaponics. This research was conducted at August until September 2016 at Fishery and Marine Faculty of Airlangga University. The experiments consisted of four treatments in five repetitions. The P0 was the treatment without cultivation media as control treatment, P1 was the treatment using zeolite, P2 was the treatment using pumice stone, P3 was the treatment using brickbat.Observations obtained from the use of technology aquaponics with the best lettuce planting medium that can affect the growth of eels that zeolite planting medium. In observation indicates the specific growth rate with planting medium zeolite $(1.19 \%)$, survival rate of eel with planting medium zeolite $(70 \%)$, high additions to the growing media lettuce zeolite $(11.39 \mathrm{~cm})$, and the lowest ammonia content of the growing media zeolite on the 28 th day $(0.03 \mathrm{mg} / \mathrm{L})$.
\end{abstract}

Keywords: Aquaponics, Growth Rate, Lactuca sativa, Monopterus albus, Cultivation Media

\section{PENDAHULUAN}

Belut merupakan salah satu produksi perikanan yang memiliki nilai ekonomis yang tinggi. Menurut Astawan
(2008) dalam Perdana (2013) 100 gram daging belut mengandung 330 kkal, protein $18,4 \%$, zat besi $20 \mathrm{mg}$, vitamin A 1.600 SI, vitamin D sepuluh kali dari 
daging, asam lemak omega 3, serta fosfor dua kali dari daging dan telur. Hal tersebut menyebabkan produksi belut meningkat dalam pasar lokal. Permintaan pasar yang tinggi dapat menyebabkan populasi belut di alam menurun karena sebagian besar belut didapatkan dari hasil tangkapan. Saat ini budidaya belut yang telah dilakukan masih menggunakan lumpur dengan campuran bahan organik lainnya sebagai media alami belut. Hal tersebut menjadi salah satu kendala dalam budidaya belut seperti persiapan wadah dengan dasar tanah lumpur yang memerlukan berbagai bahan campuran, dan waktu yang diperlukan untuk persiapan wadah yang cukup lama, pemanenan yang kurang efesien sehingga untuk memulai pemeliharaan selanjutnya memerlukan waktu kembali, serta susahnya memantau perkembangan dan kelangsungan belut selama pemeliharaan. Budidaya yang tidak terkontrol menyebabkan upaya intensifikasi budidaya belut sulit dilakukan sehingga produksi belut relatif sulit diprediksi (Perdana, 2013).

Teknologi akuaponik merupakan teknologi yang dapat meminimasi limbah nitrogen dari sisa metabolisme ikan melalui integrasi sistem produksi tanaman sayur/kembang/herbal secara hidroponik ke dalam sistem akuakultur (Sumoharjo, 2010). Teknologi akuaponik merupakan kombinasi antara menanam tanaman dan budidaya ikan dalam satu wadah. Tanaman berfungsi sebagai filter dari air limbah budidaya yang dimanfaatkan kembali untuk budidaya ikan. Salah satu faktor yang mendukung pertumbuhan akar selada sehingga mempengaruhi proses penyerapan amonia adalah media tanam selada. Peran media tanam dalam akuaponik sangat berpengaruh karena merupakan faktor pendukung penyerapan kadar amonia dari tanaman. Media yang optimal untuk pertumbuhan tanaman harus memiliki persyaratan-persyaratan sebagai tempat berpijak tanaman, mampu mengontrol kelebihan air serta memiliki sirkulasi ketersediaan udara yang baik, mampu menyuplai unsur hara yang dibutuhkan tanaman dan memiliki kemampuan mengikat air, dapat mempertahankan kelembaban di sekitar akar tanaman dan tidak mudah lapuk atau rapuh (Prayugo, 2007). Media yang digunakan dapat berupa air atau bahan poros seperti pecahan genting, pasir, kerikil dan arang sekam tergantung jenis tanaman dan tujuan penggunaannya (Nurwahyuni, 2012).

\section{METODOLOGI}

\section{Waktu dan Tempat}

Penelitian ini telah dilaksanakan pada bulan Agustus 2016 sampai September 2016 di Fakultas Perikanan dan Kelautan Universitas Airlangga.

\section{Materi Penelitian}

Peralatan Penelitian

Alat yang digunakan dalam penelitian ini adalah 20 buah akuarium berukuran $30 \times 20 \times 50 \mathrm{~cm}^{3}$, Pompasirkulasi, pH-pen, termometer, bak plastik, timbangan analitik, penggaris, jarring seser, sterefoam, Ammonia test kit, DO testkit.

\section{Bahan Penelitian}

Bahan yang digunakan dalam penelitian ini adalah belut dengan ukuran 15-25 cm sebanyak 200 ekor berasal dari Pasar Ikan Hias Gunungsari Surabaya. Pada tanaman selada, menggunakan selada varian Romain yang berumur 2 minggu setelah tumbuh dan berasal dari Farm. Kebunsayur III Merr Penjaringan Surabaya. Air tawar sebagai media pemeliharaan diperoleh dari air Perusahan Daerah Air Minum (PDAM) yang telah diendapkan terlebih dahulu.

\section{Metode Penelitian}

Kusriningrum (2012) menyatakan, penelitian (percobaan) dapat didefinisikan sebagai suatu pengamatan yang direncanakan dengan baik untuk menemukan fakta-fakta baru atau untuk memperkuat dan bahkan menolak hasil-hasil percobaan yang pernah dilakukan sebelumnya. Pengambilan data penelitian dilakukan

Diterima/submitted:10 Februari 2017 Disetujui/accepted:18 Maret 2017 
berdasarkan hasil pertumbuhan dari sayuran selada (L. sativa) dan belut (M. albus) pada sistem akuaponik.

\section{Prosedur Kerja}

Peralatan yang akan digunakan seperti akuarium, selang aerator, bak hidroponik dicuci dengan detergen lalu dibilas dengan air bersih. Kemudian dicuci dengan klorin. Setelah dicuci dengan klorin, dibilas dengan air bersih lalu dikeringkan dibawah sinar matahari. Masing-masing wadah penelitian diletakan pada rak dengan posisi sesuai dengan desain penelitian. Media tanam yang digunakan yaitu zeolite, batu apung, dan pecahan batu bata di cuci bersih lalu di rendam dengan air selama semalam. Setelah direndam, media tanam dibilas lalu dikeringkan dibawah sinar matahari. Setelah alat dan bahan dipersiapkan, aerator dipasang pada setiap akuarium. Belut yang telah diaklimatisasi dimasukkan dalam akuarium dengan jumlah 10 ekor pada tiap akuariumnya. Belut dibiarkan dan dipuasakan selama tiga hari untuk dapat beradaptasi dengan lingkungan. Setelah adaptasi tiga hari, masing-masing bak hidroponik diberikan perlakuan media tanam. Selada sebelum diletakkan didalam bak hidropnik di ukur tinggi dan lebar daun. Pengukuran panjang dan berat belut dilakukan setelah pengkuran selada.

Belut dipelihara selama 30 hari dengan pengukuran kualitas air meliputi $\mathrm{pH}$, suhu, dan DO setiap pagi dan sore. Sedangkan amonia dilakukan pengukuran pada awal dan setiap tujuh hari sekali selama 30 hari pemeliharaan. Untuk pengkuran pertumbuhan selada dilakukan setiap sembilan hari sekali sedangkan pengukuran panjang dan berat belut dilakukan pada awal dan akhir penelitian. Pakan yang diberikan adalah pakan yang harus disesuaikan dengan kebiasaan makan belut. Pakan buatan yang diberikan dalam bentuk pasta dengan kandungan protein lebih 35\%. Hal ini sesuai dengan pernyataan Santoso (2014), Pakan buatan yang diberikan dalam bentuk pasta dengan kandungan protein $35,74 \%$. Dosis pemberian pakan diberikan sebesar 3\% dari berat badan belut. Pemberian pakan dilakukan tiap sore hari dikarenakan belut bersifat nokturnal yang aktif mencari makan pada malam hari.

\section{Parameter Penelitian}

Parameter utama dalam penelitian ini adalah laju pertumbuhan, survival rate belut dan pertumbuhan selada dalam sistem akuaponik. Parameter pendukung adalah kandungan amonia serta kualitas air yang meliputi suhu, $\mathrm{pH}$, Dissolved oxygen/DO (oksigen terlarut) air media pemeliharaan selama penelitian.

\section{Analisis Data}

Rancangan yang digunakan dalam penelitian ini adalah Rancangan Acak Lengkap (RAL) yang dilakukan secara eksperimental. Penelitian ini terdiri dari lima perlakuan dengan empat kali ulangan. Data penelitian dianalisis menggunakan Analysis of Varian (ANOVA) dan dilanjutkan dengan uji lanjutan dengan menggunakan uji jarak berganda Duncan (Duncan's multiple range test) untuk mengetahui perbedaan antara perlakuan yang satu dengan perlakuan yang lainnya. Perhitungan statistik menggunakan aplikasi Statistical Product and Service (SPSS) versi16.

\section{HASIL DAN PEMBAHASAN Specific Growth Rate (SGR)}

Hasil specific growth ratedengan media tanam yang berbeda diperoleh dari selisih berat belut akhir dan awal penelitian dibagi periode penelitan dikali 100\%. Laju pertumbuhan spesifik belut $(M$. albus) selama penelitian dapat dilihat pada Tabel 1.

Berdasarkan uji Anova, terdapat perbedaan yang nyata terhadap laju pertumbuhan spesifik belut dengan media tanam selada yang berbeda $(p<0,05)$. Pertumbuhan SGR belut diperoleh yang optimal pada perlakuan P1 (1,199\%). Berdasarkan uji Duncan, perlakuan P1 
berbeda nyata dengan perlakuan $\mathrm{P} 0, \mathrm{P} 2$, dan P3. Perlakuan P0 tidak berbeda nyata dengan $\mathrm{P} 2$ dan $\mathrm{P} 3$, perlakuan $\mathrm{P} 2$ tidak berbeda nyata dengan $\mathrm{P} 0$ dan $\mathrm{P} 3$, perlakuan P3 tidak berbeda nyata dengan P0 dan P2.

Tabel 1. Data Presentase laju pertumbuhan spesifik

\begin{tabular}{cc}
\hline Perlakuan & $\begin{array}{c}\text { Pertumbuhan Laju } \\
\text { Spesifik }(\%) \pm \text { SD }\end{array}$ \\
\hline P0 & $0,396^{\mathrm{a}} \pm 0,171$ \\
P1 & $1,199^{\mathrm{b}} \pm 0,617$ \\
P2 & $0,638^{\mathrm{a}} \pm 0,191$ \\
P3 & $0,402^{\mathrm{a}} \pm 0,075$ \\
\hline
\end{tabular}

Keterangan :

P0 : Kontrol, P1 : Perlakuan dengan media tanam zeolit, P2 : Perlakuan dengan media tanam batu apung, P3 Perlakuan dengan pecahan batu bata. Notasi huruf superscript yang berbeda pada kolom yang sama menunjukkan perbandingan antar perlakuan terdapat perbedaan yang nyata $(\mathrm{P}<0,05)$.

\section{Panjang Mutlak Belut (Monopterus albus)}

Tabel 2. Rata - rata Panjang Mutlak Belut Selama Waktu Penelitian

\begin{tabular}{cc}
\hline Perlakuan & $\begin{array}{c}\text { Rata-rata Panjang } \\
\text { Mutlak Belut }(\mathrm{cm}) \pm \text { SD }\end{array}$ \\
\hline P0 & $0,740^{\mathrm{a}} \pm 0,214$ \\
P1 & $0,942^{\mathrm{b}} \pm 0,154$ \\
P2 & $0,928^{\mathrm{ab}} \pm 0,075$ \\
P3 & $0,822^{\mathrm{ab}} \pm 0,061$
\end{tabular}

Keterangan :

P0 : Kontrol, P1 : Perlakuan dengan media tanam zeolit, P2 : Perlakuan dengan media tanam batu apung, P3 Perlakuan dengan pecahan batu bata. Notasi huruf superscript yang berbeda pada kolom yang sama menunjukkan perbandingan antar perlakuan terdapat perbedaan yang nyata $(\mathrm{P}<0,05)$.
Hasil penelitian pertumbuhan panjang belut dengan media tanam yang berbeda diperoleh dari selisih panjang awal dan panjang akhir penelitian. Berdasarkan uji Anova, pertumbuhan panjang mutlak belut tidak terdapat perbedaan yang nyata karena $\mathrm{P}>0,05$. Berdasarkan uji Duncan, diperoleh hasil panjang mutlak belut pada perlakuan P1 berbeda nyata terhadap P0 tetapi tidak berbeda nyata terhadap P2 dan P3. Perlakuan P0 tidak berbeda nyata dengan $\mathrm{P} 2$ dan $\mathrm{P} 3$ tetapi berbeda nyata dengan P1.

\section{Kelulushidupan Belut (Monopterus albus)}

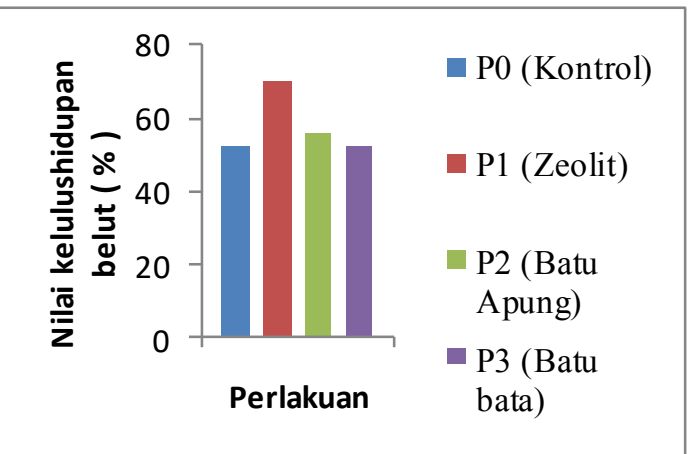

Keterangan :

P0 : Kontrol, P1 : Perlakuan dengan media tanam zeolit, P2 : Perlakuan dengan media tanam batu apung, P3 Perlakuan dengan pecahan batu bata.

Hasil kelulushidupan belut dengan media tanam yang berbeda diperoleh dari jumlah ikan pada akhir uji dibagi jumlah ikan pada awal uji dikali seratus persen. Perhitungan rata-rata setiap perlakuan pada akhir penelitian diperoleh tingkat kelulushidupan tertinggi yaitu perlakuan pada perlakuan P2 (70\%) diikuti P1 (56\%), P3 (52\%) dan P0 (52\%).

\section{Pertumbuhan Tinggi dan Lebar Daun Selada (Lactuca sativa)}

Hasil penelitian untuk pertumbuhan tinggi sayuran selada diperoleh dari perhitungan selisih tinggi sayuran selada di awal dan di akhir penelitian. Berdasarkan Uji Anova, terdapat perbedaan yang nyata 
terhadap pertumbuhan tinggi selada $(\mathrm{P}<0,05)$. Pertumbuhan optimal pada perlakuan P1 dan terendah pada perlakuan P0. Berdasarkan uji Duncan, perlakuan P1 berbeda nyata dengan P0,P2 dan P3. Perlakuan P0 berbeda nyata dengan P1,P2 dan P3. Perlakuan P2 tidak berbeda nyata dengan P3 tetapi berbeda nyata dengan P1 dan $\mathrm{P} 0$.

Tabel 3. Rata-rata Pertumbuhan Tinggi Sayuran Selada Selama Waktu Penelitian

\begin{tabular}{cc}
\hline Perlakuan & $\begin{array}{c}\text { Rata-rata Pertumbuhan } \\
\text { Tinggi Selada } \pm \text { SD }(\mathrm{cm})\end{array}$ \\
\hline P0 & $5,284^{\mathrm{a}} \pm 1,358$ \\
P1 & $11,396^{\mathrm{c}} \pm 2,179$ \\
P2 & $8,640^{\mathrm{b}} \pm 1,289$ \\
P3 & $7,406^{\mathrm{b}} \pm 0,739$
\end{tabular}

Keterangan :

P0 : Kontrol, P1 : Perlakuan dengan media tanam zeolit, P2 : Perlakuan dengan media tanam batu apung, P3 Perlakuan dengan pecahan batu bata. Notasi huruf superscript yang berbeda pada kolom yang sama menunjukkan perbandingan antar perlakuan terdapat perbedaan yang nyata $(\mathrm{P}<0,05)$.

Tabel 4. Rata-rata Pertambahan Lebar Daun Sayuran Selada Selama Waktu Penelitian

\begin{tabular}{cc}
\hline Perlakuan & $\begin{array}{c}\text { Rata-rata Pertumbuhan } \\
\text { Lebar daun } \pm \text { SD }(\mathrm{cm})\end{array}$ \\
\hline P0 & $1,998^{\mathrm{a}} \pm 1,283$ \\
P1 & $5,556^{\mathrm{b}} \pm 0,839$ \\
P2 & $4,380^{\mathrm{b}} \pm 0,933$ \\
P3 & $2,822^{\mathrm{a}} \pm 1,270$ \\
\hline
\end{tabular}

Keterangan :

P0 : Kontrol, P1 : Perlakuan dengan media tanam zeolit, P2 : Perlakuan dengan media tanam batu apung, P3 Perlakuan dengan pecahan batu bata. Notasi huruf superscript yang berbeda pada kolom yang sama menunjukkan perbandingan antar perlakuan terdapat perbedaan yang nyata( $\mathrm{P}<0,05)$.
Hasil penelitian untuk lebar daun sayuran selada diperoleh dari perhitungan selisih lebar daun sayuran selada di awal dan di akhir penelitian. Berdasarkan uji Anova terdapat perbedaan yang nyata terhadap pertumbuhan lebar daun selada $(\mathrm{p}<0,05)$. Pertumbuhan lebar daun selada yang optimal pada perlakuan P1 dan terendah pada perlakuan P0. Berdasarkan uji Duncan diketahui bahwa perlakuan P1 tidak berbeda nyata dengan P2 tetapi berbeda nyata dengan P0 dan P3. Perlakuan P0 tidak berbeda nyata dengan perlakuan P3 tetapi berbeda nyata dengan $\mathrm{P} 1$ dan $\mathrm{P} 2$.

\section{Kandungan Amonia}

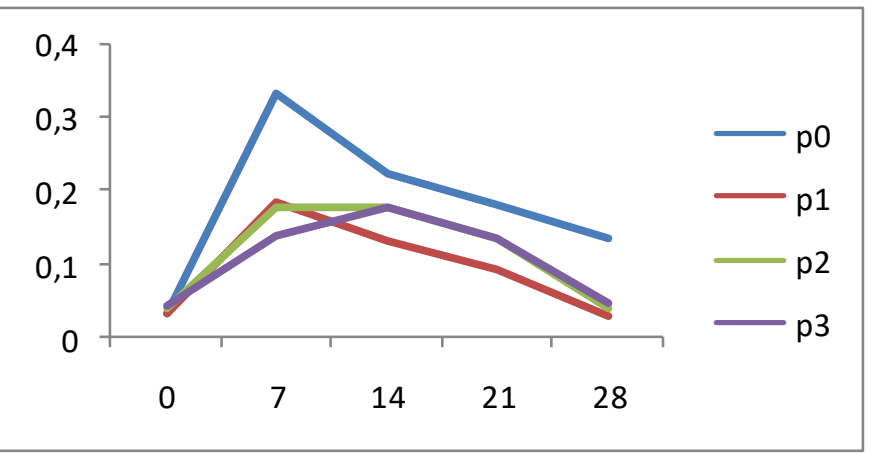

\section{Keterangan :}

P0 : Kontrol, P1 : Perlakuan dengan media tanam Zeolit, P2 : Perlakuan dengan media tanam batu apung, P3 : Perlakuan dengan media tanam pecahan batu bata.

Kandungan amonia diukur setiap tujuh hari sekali. Hasil pengamatan menunjukkan pada hari ke-0 kandungan amonia untuk semua perlakuan cenderung sama. Pada hari ke-7 semua perlakuan mengalami peningkatan kadar amonia. Peningkatan tertinggi pada perlakuan $\mathrm{P} 0$ (0,335 $\mathrm{mg} / \mathrm{L})$, lalu diikuti perlakuan $\mathrm{P} 1$ $(0,186 \mathrm{mg} / \mathrm{L})$, P2 $(0,178 \mathrm{mg} / \mathrm{L})$ dan P3 $(0,138 \mathrm{mg} / \mathrm{L})$. Perlakuan P3 mengalami peningkatan kandungan amonia, sedangkan P2 kandungan amonia tidak mengalami perubahan. Untuk perlakuan P1 dan P0 mengalami penurunan pada hari ke-14. Pada hari ke-21 semua perlakuan mengalami penurunan kandungan amonia. Pada hari ke-28 kandungan amonia pada setiap 
perlakuan mengalami penurunan. Penurunan terendah terdapat pada perlakuan $\mathrm{P} 2$ $(0,03 \mathrm{mg} / \mathrm{L})$ di akhir pengamatan.

\section{Parameter Kualitas Air}

Parameter kualitas air yang diukur meliputi suhu, $\mathrm{pH}$, oksigen terlarut (DO), nitrat dan nitrit. Tabel dibawah ini menunjukkan kisaran parameter kualitas air media budidaya belut yang diukur selama penelitian.

Tabel 5. Kisaran parameter kualitas air media budidaya belut

\begin{tabular}{|c|c|c|c|}
\hline \multirow{2}{*}{ Perlakuan } & \multicolumn{3}{|c|}{$\begin{array}{c}\text { Kisaran Parameter Kualitas } \\
\text { Air }\end{array}$} \\
\hline & $\begin{array}{c}\text { Suhu } \\
\left({ }^{\circ} \mathrm{C}\right)\end{array}$ & $\mathrm{pH}$ & $\begin{array}{c}\mathrm{DO} \\
(\mathrm{mg} / \mathrm{L})\end{array}$ \\
\hline P0 & $27-30$ & $7,7-8,3$ & $4-6$ \\
\hline P1 & $27-30$ & $7,7-8,3$ & $4-6$ \\
\hline $\mathrm{P} 2$ & $27-30$ & $7,8-8,4$ & $4-6$ \\
\hline P3 & $27-30$ & $7,7-8,4$ & $4-6$ \\
\hline
\end{tabular}

Keterangan :

P0 : Kontrol, P1 : Perlakuan dengan media tanam zeolit, P2 : Perlakuan dengan media tanam batu apung, P3 : Perlakuan dengan media tanam pecahan batu bata.

Berdasarkan data pengukuran kualitas air diperoleh kisaran suhu $\left(27-30^{\circ}\right.$ C), $\mathrm{pH}(7,7-8,4)$ dan $\mathrm{DO}(4-6 \mathrm{mg} / \mathrm{L})$ selama pengamatan berada pada kondisi yangmendukung untuk pertumbuhan belut. Hal ini sesuai dengan pernyataan Kordi (2011) belut tumbuh dan hidup dengan baik pada suhu $25-32^{\circ} \mathrm{C}$ dan pada $\mathrm{pH}$ 6-7. Oksigen terlarut (Dissolved Oxygen/DO) untuk budidaya belut yang baik yaitu minimal $5 \mathrm{mg} / \mathrm{L}$ (Boyd, 1982 dalam Purnama, 2013). pH optimal pada tanaman untuk menyerap nutrient berkisar pada 55-6,5 (Rakocy et al., 2006 dan Tyson, 2007), sementara menurut Rakocy et al., (2006) proses nitrifikasi terjadi apabila sistem akuaponik memiliki nilai $\mathrm{pH}$ berkisar 7-9. Proses nitrifikasi berjalan lambat apabila $\mathrm{pH}$ dibawah 7 dan ketika $\mathrm{pH}$ kurang dari 6 proses nitrifikasi perlahan lahan berhenti (Nelson, 2008 dalam Ratannanda, 2014).

Berdasarkan pengamatan dari beberapa parameter diatas membuktikan bahwa penggunaan media tanam selada berupa zeolit mempengaruhi laju pertumbuhan belut ( $M$. albus). Hal ini dikarenakan zeolit berperan aktif dalam membantu tanaman mereduksi bahan organik diperairan sesuai dengan pendapat Wahyuni et al., 2004; Tsitsisvi, 1980 dan Blanchard 1984 dalam LAS ( 2007) yaitu zeolit mempunyai kemampuan menyerap ammonia untuk limbah indstri dan peternakan sebesar 99\% melalui kemampuan tukar ionnya. Zeolit juga mempunyai kemampuan menyerap, dengan permukaannya yang kasar memberikan tempat untuk bakteri dalam bentuk biofilm sehingga proses oksidasi bahan organic secara biologi dimedia biofilter (Nurhidayat, 2009). Pada perlakuan tanpa menggunakan media tanam memperoleh hasil pertumbuhan belut yang terendah. Hal ini diduga kinerja filter hanya padatan aman tanpa adanya bantuan filter mekanik berupa agregat yang digunakan sebagai media tanam. Zeolit membantu tanaman dalam mereduksi amonia sesuai dengan hasil pengukuran amonia terendah pada perlakuan media tanam zeolit. Berdasarkan pernyataan Hidayat (2009) zeolit mempunyai sifat mampu menyerap dan sebagai media menempelnya mikroorganisme (biofilm) yang dapat memanfaatkan berbagai unsur yang tersuspensi dalam air dan diserap bersama bahan makanan organisme. Kisaran amonia pada semua perlakuan masih aman bagi ikan. Menurut Sawyer dan Mc Carty (1978) dalam Effendi (2003) kadar amonia bebas yang tidak terionisasi sebaiknya tidak lebih dari $0,2 \mathrm{mg} / \mathrm{L}$. Konsentrasi amonia 0,4-3,1 $\mathrm{mg} / \mathrm{L}$ dapat menyebabkan kematian sebesar $50 \%$ dari populasi ikan dalam waktu 96 jam (Boyd, 1982 dalam Ratannanda, 2011). 


\section{KESIMPULAN DAN SARAN Kesimpulan}

Kesimpulan yang diperoleh dari pembahasan di atas adalah media tanam selada dapat mempengaruhi laju pertumbuhan belut dan media tanam yang optimal dalam mempengaruhi laju pertumbuhan belut adalah media tanam zeolit.

\section{Saran}

Saran yang diperoleh dari pembahasan diatas adalah melakukan penelitian dan kajian lebih lanjut dengan kombinasi media tanam selada.

\section{DAFTAR PUSTAKA}

Effendi, H. 2003. Telaah Kualitas Air bagi Pengelolaan Sumber Daya dan Lingkungan Perairan. Kanisius. Yogyakarta.

Kusriningrum, R.S. 2012. Buku Ajar Perencanaan Percobaan. Dani Abadi Cetakan Pertama. Fakultas Kedokteran Hewan. Universitas Airlangga. Surabaya. Hal 5-98.

Nurhidayat. 2009. Efektivitas Kinerja Media Biofilter Dalam Sistem Resirkulasi Terhadap Kualitas Air, Pertumbuhan dan Kelangsungan Hidup Ikan Red Rainbow (Glossolepis inasus weber). Skripsi Pascasarjana Intitut Pertanian Bogor. Bogor

Nurwahyuni, E. 2012. Optimalisasi Pekarangan Melalui Budidaya Tanaman Secara Hidroponik. Jurnal Prosiding Seminar Nasional.

Perdana. B.P. 2013. Kinerja Produksi Belut (Monopterus albus) Pada Media Budidaya Yang Berbeda. Skripsi Departemen Budidaya Perairan Fakultas Perikanan dan Kelautan Intitut Pertanian Bogor Bogor.

Rakocy, J. E., Massor, M. P., and Losordo, T.M. 2006. Recirculating Aquaculture Tank Production Systems: Aquaponics Integrating Fish and Plant Culture. SRAC Publication No. 454. 16pp.
Ratannanda, R. 2015. Pemberian Waktu Tetensi Sistem Akuaponik Untuk Mereduksi Limbah Budidaya Ikan Nila (Oreochromis sp.). Skripsi. Departemen Budidaya Perairan Fakultas Perikanan dan Ilmu Kelautan. Institute Teknologi Bandung. Bogor

Sibarani, O.A. 2013. Pengaruh Pemberian Em4 Pada Media Biofilter Terhadap Kelangsungan Hidup Dan Laju Pertumbuhan Ikan Nilem (Osteochilus Hasselti) Dengan Sistem Akuaponik. Skripsi. Fakultas Perikanan dan Ilmu Kelautan Program Studi Perikanan Jati Angor. Universitas Padjadjaran.

Sumoharjo. 2010. Penyisihan Limbah Nitrogen pada Pemeliharaan Ikan Nila Oreochromis niloticus dalam Sistem Akuaponik : Konfigurasi DesainBioreaktor. Tesis. Sekolah Pascasarjana Institut Pertanian Bogor. Bogor. 101 hal.

Tyson, R.V., Simonne. E.H., and Treadwell. D.D. 2008. Reconciling $\mathrm{pH}$ for Ammonia Biofiltration and Cucumber Yeild in a Recirculating Aquaponic System with Perlite Biofilters. HortScience. 43(3): 719724.

Wahap, N., A. Estim., A.Y.S Kian., S. Senoo dan S. Mustafa. 2010. Producing Organic Fish and Mint in an Aquaponic System. Borneo Marine Research Institue, Sabah, Malaysia. 